\title{
TANOUSIA ZRMANJAE (BRUSINA, 1866) (CAENOGASTROPODA: TRUNCATELLOIDEA: HYDROBIIDAE): A LIVING FOSSIL
}

\author{
LUBOŠ BERAN ${ }^{1}$, SEBASTIAN HOFMAN² ${ }^{2}$ ANDRZEJ FALNIOWSKI ${ }^{3 *}$ \\ ${ }^{1}$ Nature Conservation Agency of the Czech Republic, Regional Office Kokořínsko - Máchův kraj Protected \\ Landscape Area Administration, Česká 149, CZ 27601 Mělník, Czech Republic \\ ${ }^{2}$ Department of Comparative Anatomy, Institute of Zoology, Jagiellonian University, Gronostajowa 9, 30- \\ 387 Cracow, Poland \\ ${ }^{3}$ Department of Malacology, Institute of Zoology, Jagiellonian University, Gronostajowa 9, 30-387 Cracow, \\ Poland (e-mail: andrzej.falniowski@uj.edu.pl) \\ * corresponding author
}

ABSTRACT: A living population of Tanousia zrmanjae (Brusina, 1866) was found in the mid section of the Zrmanja River in Croatia. The species, found only in the freshwater part of the river, had been regarded as possibly extinct. A few collected specimens were used for this study. Morphological data confirm the previous descriptions and drawings while molecular data place Tanousia within the family Hydrobiidae, subfamily Sadlerianinae Szarowska, 2006. Two different sister-clade relationships were inferred from two molecular markers. Fossil Tanousia, represented probably by several species, are known from interglacial deposits of the late Early Pleistocene to the early Middle Pleistocene of several European countries. Thus $T$. zrmanjae may be regarded as a living fossil restricted to the short section of the Zrmanja River.

KEY WORDS: protoconch, radula, reproductive organs, DNA, COI, 18S, phylogeny, Pleistocene

\section{INTRODUCTION}

The Zrmanja River (Figs 1-2) in Croatia, $69 \mathrm{~km}$ long, with the catchment area of $907 \mathrm{~km}^{2}$, is one of the European hot spots of freshwater gastropod diversity. It is inhabited by 16 species, five of them endemic (STRONG et al. 2008), or - according to BERAN (2011) - even 22 species. Truncatelloidea are represented by three species found in the brackish section below the Jankovica Buk waterfalls, and by eight species in the freshwater part above Jankovica Buk. Four of the freshwater species: Belgrandiella krupensis Radoman, 1973, B. zermanica Radoman, 1973, Islamia zermanica Radoman, 1973, and Tanousia zrmanjae (Brusina, 1866) (= Lithoglyphulus tedanicus Schlickum et Schütt, 1971), were described from this part including its tributary, the Krupa River (RADOMAN 1985). However, the species distinctness of Belgrandiella krupensis and B. zermanica is doubtful (FALNIOWSKI \& BERAN 2015).
BRUSINA (1866) described Limnaea zrmanjae, later included in the Hydrobiidae, and the genus Tanousia Bourguignat (in SERVAIN 1881, see: KABAT \& HERSHLER 1993). In the same paper she described the genus Sandria, a junior objective synonym of Tanousia (KABAT \& HERSHLER 1993). Later, SCHLICKUM \& SCHÜTT (1971) described Lithoglyphulus tedanicus, identical with Tanousia zrmanjae, thus creating a junior synonym. RADOMAN $(1973,1983)$ described and illustrated the radula, penis and female reproductive organs of this species, classifying it, with reservations, into a distinct family Lithoglyphulidae.

According to the IUCN Red List, T. zrmanjae is Critically Endangered (Possibly Extinct), based on the habitat loss in the type locality (FALNIOWSKI 2011). It occurs exclusively in the freshwater parts of the Zrmanja River. The river was dammed in its lower part (which divides the site with T. zrmanjae) 

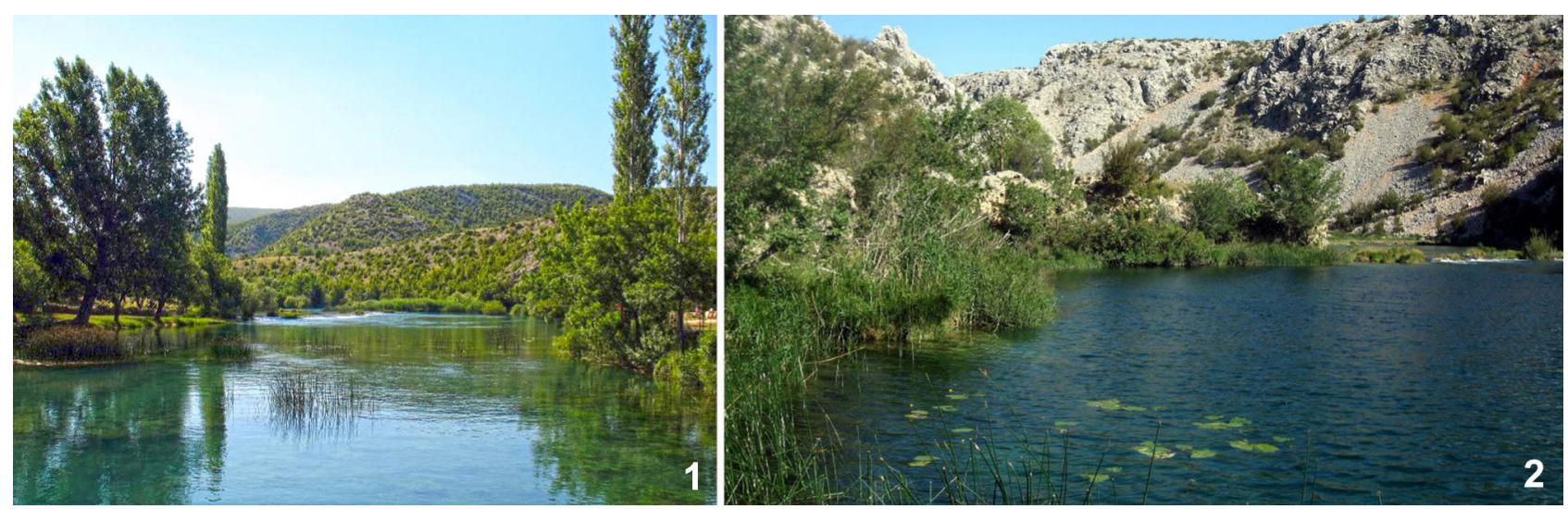

Figs 1-2. Zrmanja River at its mid freshwater section

and in its upper course; due to its karstic character, during dry periods the river represents a system of stagnant pools (like that at Kaštel Zegarski) interspersed with dry river bed (like that at Ervenik): only few gastropod species live in its upper part. A small living population was found in the mid, freshwater section of the river (BERAN 2011) and later also at a locality upstream of this site. The aim of the present paper was to check the morphological characters of the species and, applying molecular markers, to resolve its phylogenetic relationships.

\section{MATERIAL AND METHODS}

A few specimens of Tanousia zrmanjae were collected at Dramotići, Zrmanja River, Croatia at $44^{\circ} 11 ' 31.6 " \mathrm{~N}, 15^{\circ} 47^{\prime} 05^{\prime \prime} \mathrm{E}$ on 29.06 .2014 . The snails were collected from the sediment using a metal sieve. Individuals for molecular analyses were washed in $80 \%$ ethanol and left to stand in it for ca. 12 hours. Afterwards, the ethanol was changed twice during 24 hours and, after a few days, $80 \%$ ethanol was replaced with $96 \%$ ethanol. The samples were then stored at $-20^{\circ} \mathrm{C}$ prior to DNA extraction.

The snails were dissected using a NIKON SMZ18 stereo-microscope with dark field and phase contrast, and shells and penes photographed with CANON EOS 50D digital camera. Protoconchs and radulae were examined using a JEOL JSM-5410 scanning electron microscope, applying the techniques described by FALNIOWSKI (1990).

DNA was extracted from foot tissue of each snail. The tissue was hydrated in TE buffer $(3 \times 10$ min.); total genomic DNA was extracted with the SHERLOCK extracting kit (A\&A Biotechnology), and the final product was dissolved in $20 \mu \mathrm{l}$ TE buffer. The PCR reaction was performed with the following primers: LCO1490 (5'-GGTCAACAAATCATAAAG ATATTGG-3') (FOLMER et al. 1994) and COR722b (5'-TAAACTTCAGGGTGACCAAAAAATYA-3') (WILKE \& DAVIS 2000) for the cytochrome oxidase subunit I (COI) mitochondrial gene and SWAM18SF1 (5'-GAATGGCTCATTAAATCAGTCGAGGTTCCT TAGATGATCCAAATC-3'), and SWAM18SR1 (5'-ATCCTCGTTAAAGGGTTTAAAGTGTACTCAT TCCAATTACGGAGC-3') for the 18S ribosomal
DNA (18S) gene (ATTWOoD et al., 2003). The PCR conditions were as follows: $\mathrm{COI}$ - initial denaturation step of $4 \mathrm{~min}$ at $94^{\circ} \mathrm{C}$, followed by 35 cycles of 1 $\min$ at $94^{\circ} \mathrm{C}, 1 \mathrm{~min}$ at $55^{\circ} \mathrm{C}, 2 \mathrm{~min}$ at $72^{\circ} \mathrm{C}$, and a final extension of 4 min at $72^{\circ} \mathrm{C} ; 18 \mathrm{~S}$ - initial denaturation step of 4 min at $94^{\circ} \mathrm{C}$, followed by 40 cycles of $45 \mathrm{~s}$ at $94^{\circ} \mathrm{C}, 45 \mathrm{~s}$ at $51^{\circ} \mathrm{C}, 2 \mathrm{~min}$ at $72^{\circ} \mathrm{C}$ and a final extension step of $4 \mathrm{~min}$ at $72^{\circ} \mathrm{C}$. The total volume of each PCR reaction mixture was $50 \mu$ l. To check the quality of the PCR products $10 \mu \mathrm{l}$ of the PCR product was run on a $1 \%$ agarose gel. The PCR products were purified using Clean-Up columns (A\&A Biotechnology) and the purified PCR products were amplified in both directions using BigDye Terminator v3.1 (Applied Biosystems), following the manufacturer's protocol and with the primers described above. The sequencing reaction products were purified using ExTerminator Columns (A\&A Biotechnology); DNA sequences then underwent electrophoresis on an ABI Prism sequencer.

Sequences were initially aligned with MUSCLE (EDGAR 2004) in MEGA 6 (TAMURA et al. 2013) and then checked manually in Bioedit 7.1.3.0 (HALL 1999). The saturation test of XIA et al. (2003) was performed using DAMBE (XIA 2013) and revealed no saturation in any of the sequences studied. The sequences obtained from Tanousia specimens in the present work were used in the phylogenetic analysis with other sequences obtained from GenBank (Table 1). A maximum likelihood (ML) approach was conducted in RAxML v8.0.24 (STAMATAKIS 2014). One thousand searches were initiated with starting 
Table 1. Taxa used for phylogenetic analyses, with their GenBank Accession Numbers and references

\begin{tabular}{llll}
\hline \multicolumn{1}{c}{ Species } & 18S GB\# & COI GB\# & \multicolumn{1}{c}{ References } \\
\hline Agrafia wiktori Szarowska et Falniowski, 2011 & JF906758 & JF906762 & SZAROWSKA \& FALNIOWSKI (2011) \\
Alzoniella finalina Giusti et Bodon, 1984 & AF367686 & AF367650 & WILKE et al. (2001) \\
Anagastina zetavalis (Radoman, 1973) & EF070622 & EF070616 & SZAROWSKA (2006) \\
Avenionia brevis (Draparnaud, 1805) & AF367670 & AF367638 & WILKE et al. (2001) \\
Belgrandiella kusceri (Wagner, 1914) & JX970574 & JX970610 & WILKE et al. (2013) \\
Dalmatinella fluviatilis Radoman, 1973 & KC344539 & KC344541 & FALNIOWSKI \& SZAROWSKA (2013) \\
Daphniola graeca Radoman, 1973 & EF070624 & EF070618 & SZAROWSKA (2006) \\
Fissuria boui Boeters, 1981 & AF367690 & AF367654 & WILKE et al. (2001) \\
Graecoarganiella parnassiana Falniowski et Szarowska, 2011 & JN202341 & JN202348 & FALNIOWSKI \& SZAROWSKA (2011) \\
Graziana alpestris (Frauenfeld, 1863) & AF367673 & AF367641 & WILKE et al. (2001) \\
Grossuana codreanui (Grossu, 1946) & EF061916 & EF061919 & SZAROWSKA et al. (2007) \\
Hauffenia tellinii (Pollonera, 1898) & AF367672 & AF367640 & WILKE et al. (2001) \\
Horatia klecakiana Bourguignat, 1887 & KJ159127 & KJ159128 & SZAROWSKA \& FALNIOWSKI (2014) \\
Hydrobia acuta (Draparnaud, 1805) & AF367680 & AF278808 & WILKE \& DAVIS (2000) \\
Islamia piristoma Bodon et Cianfanelli, 2001 & AF367671 & AF367639 & WILKE et al. (2001) \\
Montenegrospeum bogici (Pešić et Glöer, 2012) & KM875509 & KM875510 & FALNIOWSKI et al. (2014) \\
Radomaniola callosa (Paulucci, 1881) & AF367685 & AF367649 & WILKE et al. (2001) \\
Sadleriana fluminensis (Küster, 1853) & AF367683 & AY273996 & WILKE et al. (2001) \\
Tanousia zrmanjae (Brusina, 1866) & KU041813 & KU041811 & present study \\
Trichonia kephalovrissonia Radoman, 1973 & EF070630 & EF070619 & SZAROWSKA (2006) \\
Truncatella scalaris (Michaud, 1830) & JX970596 & JX970621 & WILKE et al. (2013) \\
\hline & & &
\end{tabular}

trees obtained through randomised stepwise addition maximum parsimony method. The tree with the highest likelihood score was considered as the best representation of the phylogeny. Bootstrap sup- port was calculated with 1,000 replicates and summarised on the best ML tree. RAxML analyses were performed using free computational resources of the CIPRES Science Gateway (MILLER et al. 2010).

\section{RESULTS}

\section{MORPHOLOGY}

The shell (Figs 3-6) is characteristic, nearly neritiform, although with relatively high spire, unusually thick-walled (for a hydrobiid), light cream-coloured, slightly variable. The protoconch (Fig. 7) is smooth, without any sculpture even under high magnification. The radula is similar to the one illustrated by RADOMAN (1983), with a very small central tooth lacking basal cusps, and lateral teeth (Fig. 8) with unusually massive bases (nomenclature after HERSHLER \& PONDER 1998). The female reproductive organs

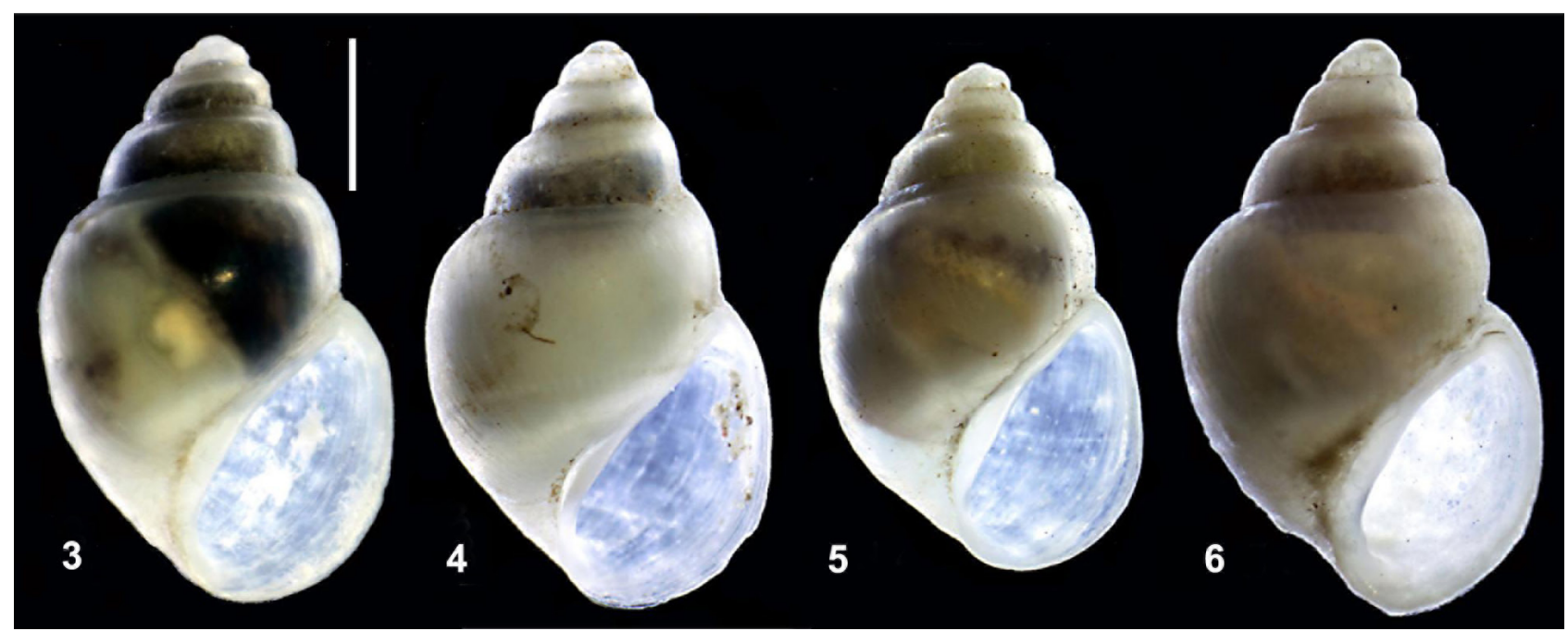

Figs 3-6. Shells of Tanousia zrmanjae; scale bar $1 \mathrm{~mm}$ 

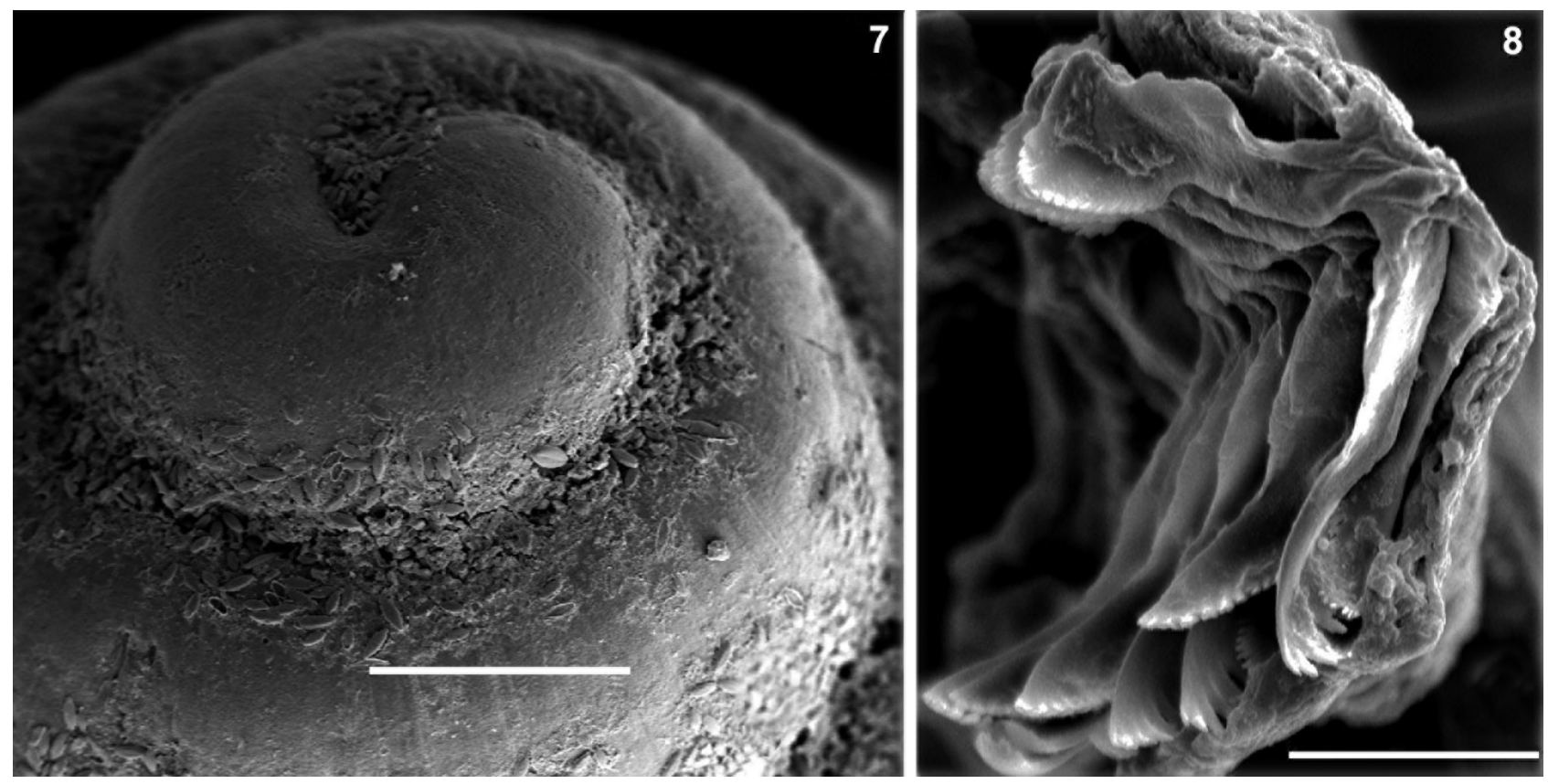

Figs 7-8. Tanousia zrmanjae: 7 - protoconch (scale bar $100 \mu \mathrm{m}$ ), 8 - lateral and marginal radular teeth (scale bar $20 \mu \mathrm{m})$

(Fig. 9) are similar to those presented by RADOMAN (1983), with two proportionally large seminal receptacles ( $\mathrm{rs}_{1}$ and $\mathrm{rs}_{2}$ per RADOMAN 1973, 1983), $\mathrm{rs}_{2}$ much larger than $\mathrm{rs}_{1}$, and a moderately large bursa copulatrix. The penis is relatively large and massive (Fig. 10), simple, without any outgrowths, terminally with a long filament (Fig. 11), similar to the one drawn by RADOMAN (1983).

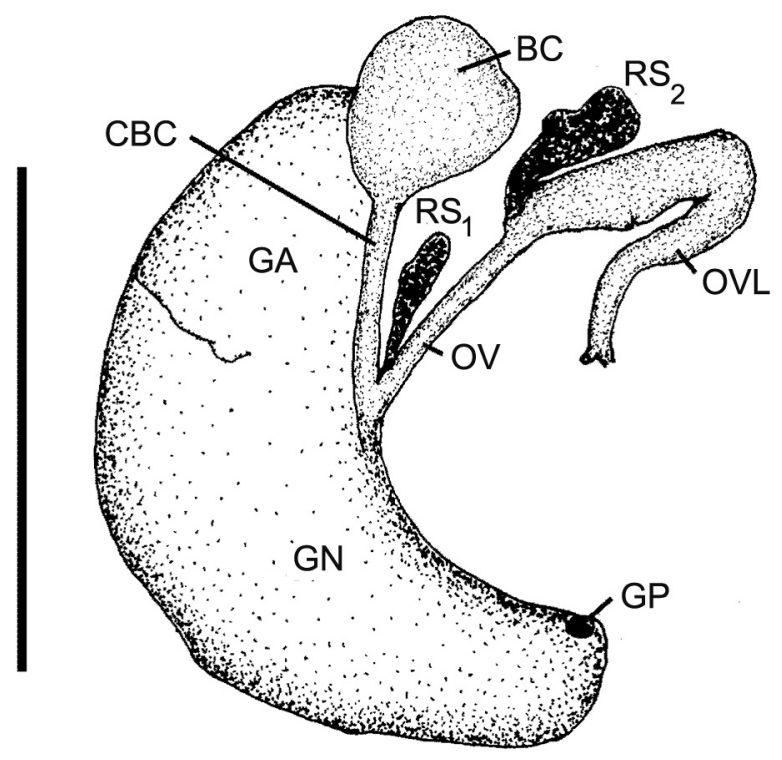

Fig. 9. Renal and pallial section of female reproductive organs of Tanousia zrmanjae (BC - bursa copulatrix, CBC - duct of bursa copulatrix, GA - albumen gland, GN nidamental gland, GP - gonoporus, OV - oviduct, OVL loop of (renal) oviduct, $\mathrm{RS}_{1}, \mathrm{RS}_{2}$ - receptaculum seminis, symbols after RADOMAN 1973, 1983; scale bar $1 \mathrm{~mm}$ )

\section{MOLECULAR PHYLOGENY}

We obtained for Tanousia zrmanjae two sequences for the COI gene (552 bp, GenBank Accession numbers KU041811-KU041812) and two for the 18S (414 bp, GenBank Accession numbers KU041813KU041814).

In the COI analyses (197 polymorphic sites) (Fig. 12) our two identical sequences of Tanousia were sister to Dalmatinella fluviatilis and Montenegrospeum bogici, with p-distances of 0.158 and 0.160 , respectively (bootstrap support 79\%). The divergence level

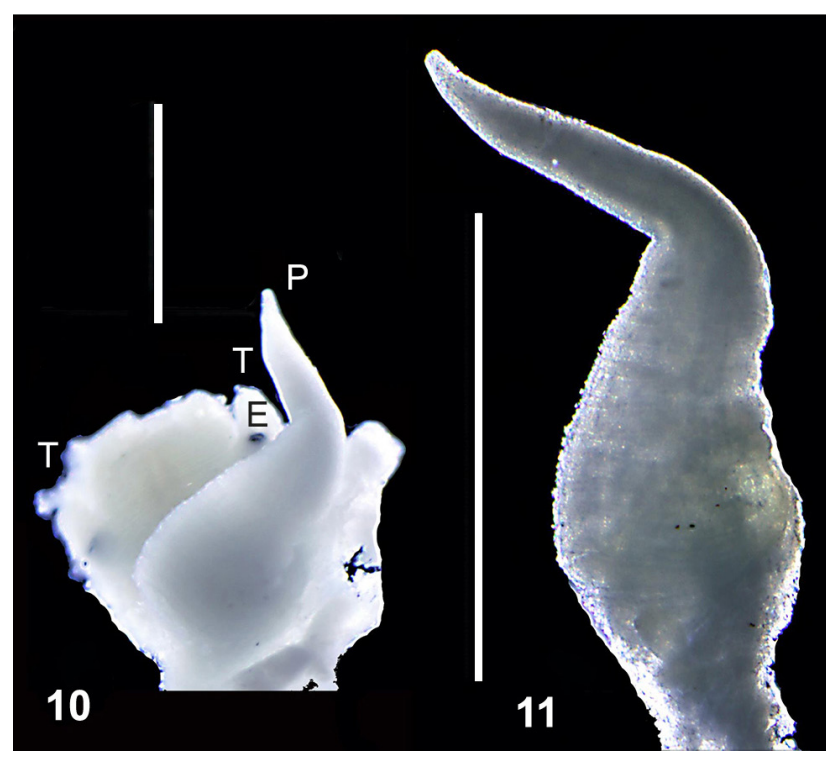

Figs 10-11. Tanousia zrmanjae: 10 - head with penis (E eye, $\mathrm{P}$ - penis, $\mathrm{T}$ - cephalic tentacle), 11 - penis; scale bars $1 \mathrm{~mm}$ 


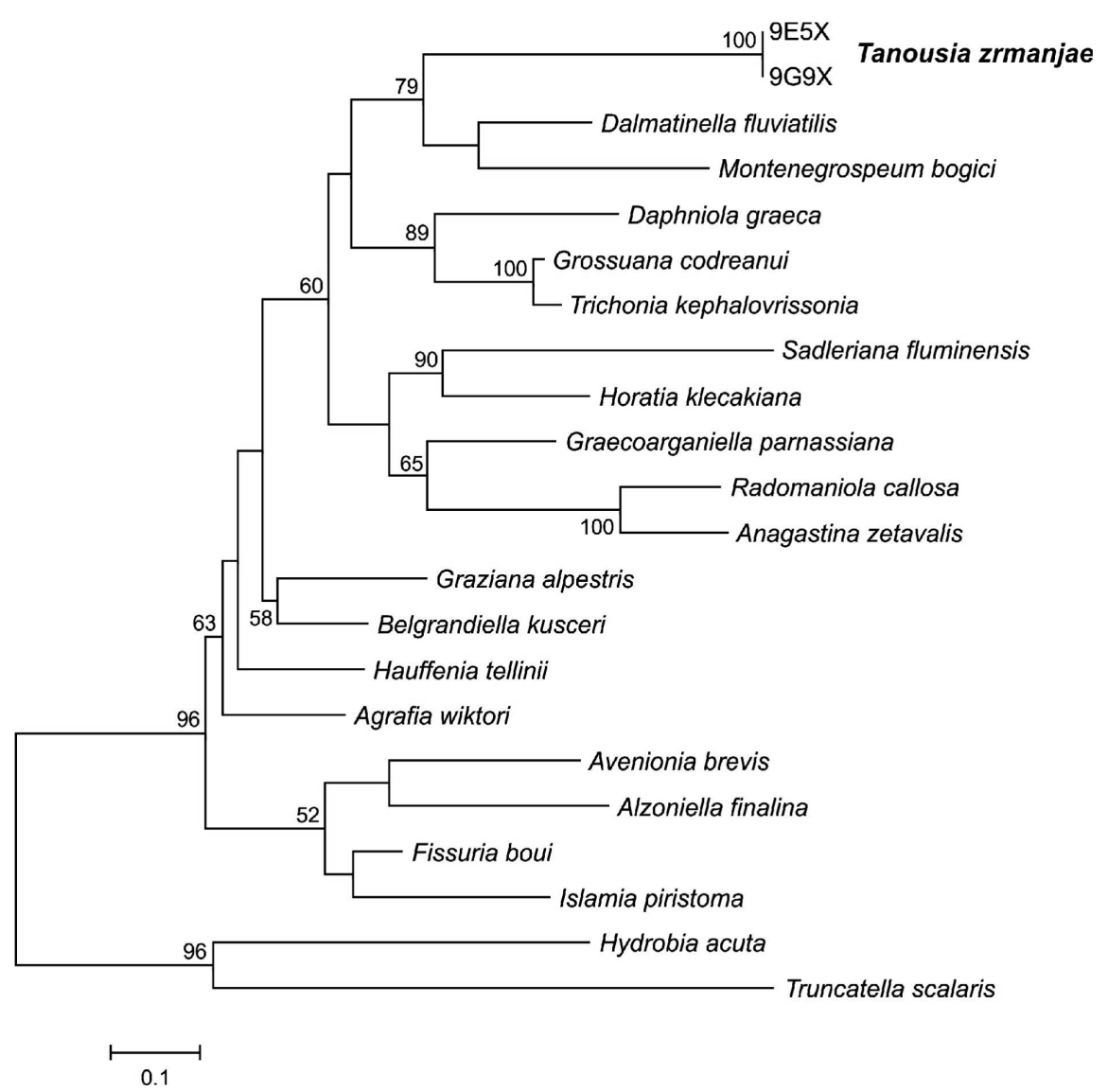

Fig. 12. Maximum likelihood tree of COI sequences, 10,000 replicates; bootstrap supports given if $>50 \%$

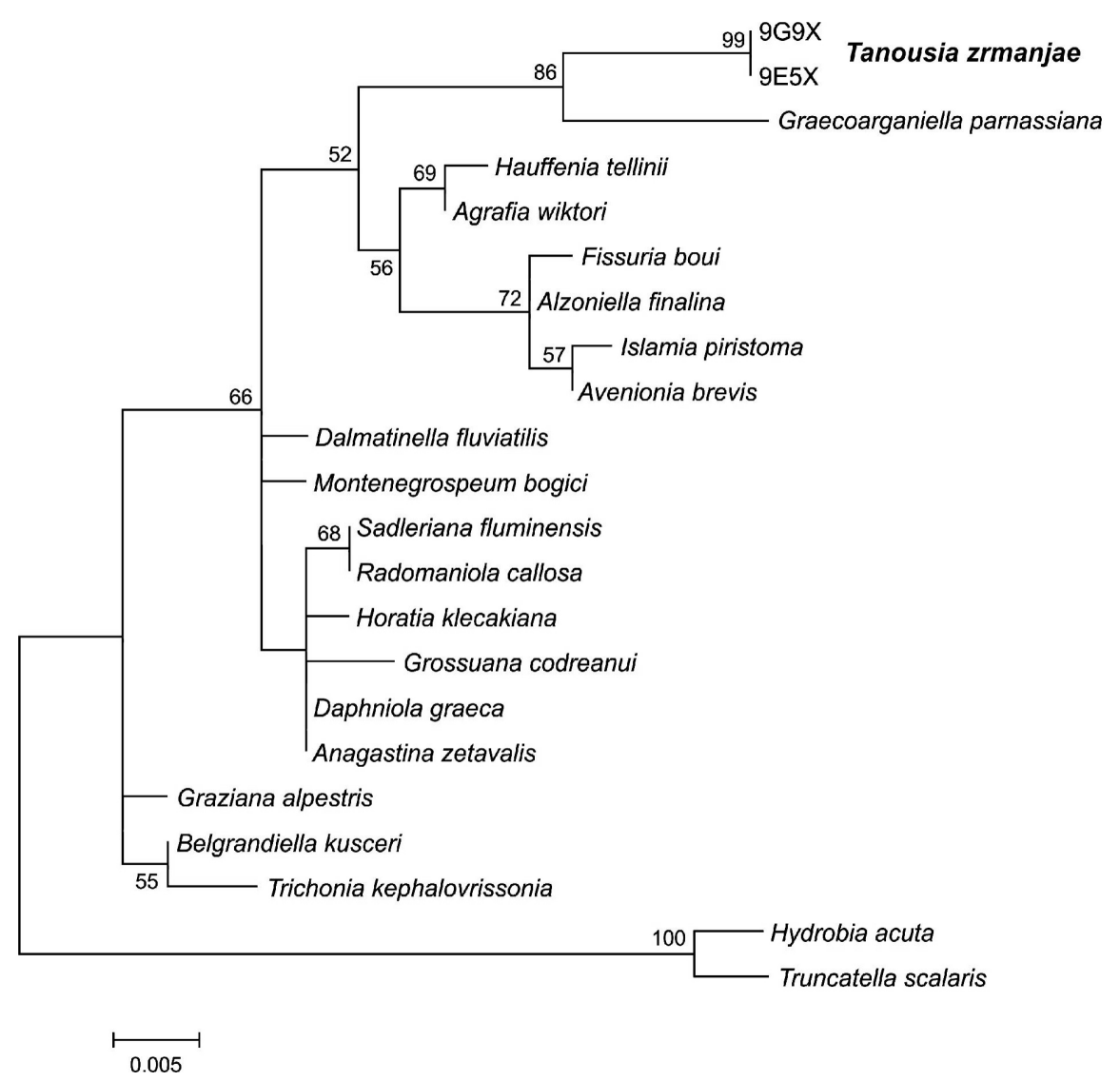

Fig. 13. Maximum likelihood tree of $18 \mathrm{~S}$ with 10,000 replicates; bootstrap supports given if $>50 \%$ 


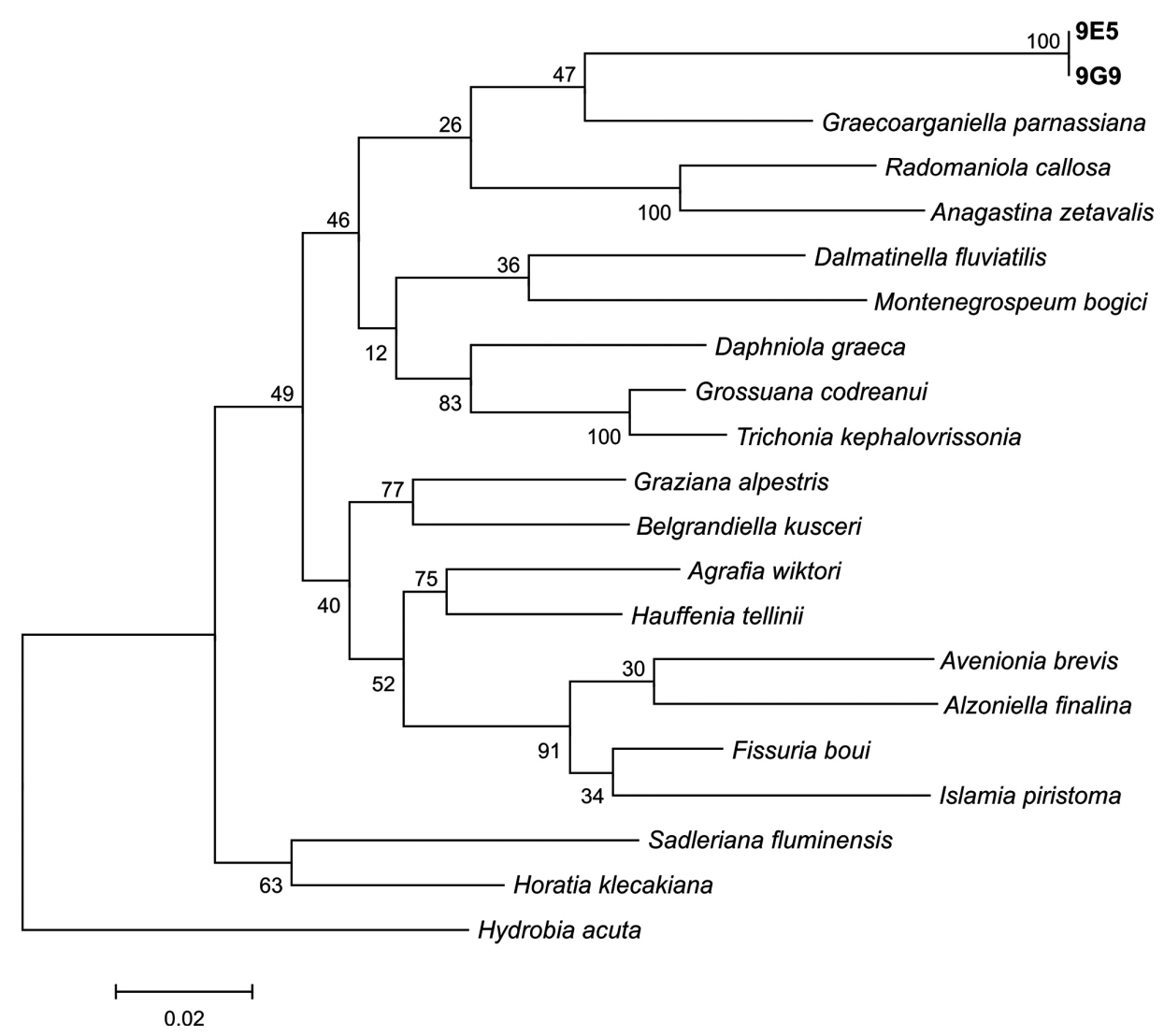

Fig. 14. Maximum likelihood tree of the two concatenated sequences (18S and COI), bootstrap supports (10,000 replicates)

between Tanousia and the other Sadlerianinae species varied from $16 \%$ (for Dalmatinella fluviatilis) to $19.3 \%$ (for Sadleriana fluminensis) and exceeded $20 \%$ for the outgroups.

In $18 S$ analyses (32 polymorphic sites) two sequences of Tanousia were also identical (Fig. 13) and sister to Graecoarganiella parnassiana (with p-distance 0.019 , bootstrap support $86 \%$ ). The ML tree for combined COI and $18 \mathrm{~S}$ was characterised by very

\section{DISCUSSION}

Our morphological data are compatible with the descriptions and illustrations of RADOMAN (1973, 1983). According to RADOMAN $(1973,1983)$ Tanousia belong to a distinct family Lithoglyphulidae, although in his opinion the relationships of the genus remained unclear. Morphological data, however, suggested a rather close relationship with Dalmatinella Radoman, 1973. Our molecular data without doubt placed Tanousia within the family Hydrobiidae, subfamily Sadlerianinae Szarowska, 2006. Thus, the monogeneric family Lithoglyphulidae Radoman, 1973 is no longer valid.

Unfortunately, the two molecular markers indicate two different sister-clade relationships (Figs 12, 13), each well supported. This is not unusual, since the evolution of different genes - especially a mitochon- low bootstrap supports, and thus numerous polytomies (Fig. 14). This confirmed that the histories of the two genes were different. Despite different sister-species relationships of Tanousia, both studied loci clearly confirm that the genus belongs to the Hydrobiidae Troschel, 1857, subfamily Sadlerianinae Szarowska, 2006. Thus, the monogeneric family Lithoglyphulidae Radoman, 1973 should be rejected.

drial vs. a nuclear gene - need neither be identical, nor reflect the evolution of the organism (e.g. AVISE 2000, NEI \& KUMAR 2000). Considering the level of distinctness ( $\mathrm{p}$-distances) for each gene, long-branch-attraction may be involved as well. In $18 S$ the alignment is not certain. The tree inferred with COI (Fig. 12), with Dalmatinella/Montenegrospeum as the sister clade, is much more congruent with the morphological data.

According to WILKE (2003), an estimate of $1.83 \pm 0.21 \%$ population divergence per million years could be applied for COI in the Hydrobiidae, as long as the data are ultrametric. With all the necessary reservations, the estimated time of divergence between Tanousia and its sister taxa is about 9 Mya, thus Tortonian in the Miocene, although the beginning of the Messinian is also within the estimated 
range. This illustrates the level of longevity of this distinct lineage. It should be noted, however, that the presented tree is not ultrametric, and that different methods of relaxation of the ultrametricity resulted in estimates of about 2 or 18 Mya, respectively.

In the truncatelloidean gastropods, the shell is usually not very useful for genus determination. However, because the shell of Tanousia is rather characteristic, the fossil record could be considered in this case. Fossil Tanousia, represented by several species, are known from Denmark (MADSEN \& NORDMANN 1901), England (SCHLICKUM 1974, PreECE 1990, 2001), the Netherlands (MEIJER 1989, GITTENBERGER et al. 1998, GLÖER 2002), France (SCHLICKUM 1974), Hungary (ROTH 1881, BRUSINA 1902), Ukraine (ANDRUSOV 1890, KONDRASHOV 2007), Romania (HERBICH \& NEUMAYR 1875, JeKEliUs 1932, 1944), Italy (ESU \& KOTSAKIS 1996, ESU \& GIANOLLA 2007, ESU 2008), and Greece (SCHÜTT 1976). The stratigraphic range of the genus is the late Early Pleistocene to the early Middle Pleistocene, thus till about 0.7 Mya, all the records coming from interglacial deposits (references cited above), and from lowland river deposits. Thus, the only extant species $-T$. zrmanjae - may be regarded as a living fossil, and its present restricted distribution (a short section of one river) most probably reflects the existence of a glacial refugium at this place. However, there are no data on the real existence and size of the refugium, most probably not restricted to this short section of the Zrmanja River, and transport (by birds?) of Tanousia from another area cannot be excluded.

\section{ACKNOWLEDGEMENTS}

The study was supported by a grant from the National Science Centre (2012/05/B/NZ8/ 00407) to MAGDALENA SZAROWSKA.

\section{REFERENCES}

ANDRUSOV N. 1890. Kerchenskiy izvestnyak i ego fauna. Zapiski Imperatorskago S.-Petersburgskogo Mineralogicheskogo Obshchestva 2, 26: 193-344.

AtTwood S. W., Ambu S., Meng X.-H., Upatham E. S., XU F.-S., SOUTHGATE V. R. 2003. The phylogenetics of Triculine snails (Rissooidea: Pomatiopsidae) from SouthEast Asia and southern China: historical biogeography and the transmission of human schistosomiasis. J. Mollus. Stud. 69: 263-271. http://dx.doi.org/10.1093/ mollus/69.3.263

AVISE J. C. 2000. Phylogeography. The history and formation of species. Harvard University Press, Cambridge, MA and London.

BERAN L. 2011. Non-marine molluscs (Mollusca: Gastropoda, Bivalvia) of the Zrmanja River and its tributaries (Croatia). Nat. Croat. 20: 397-409.

BouRguignAT J. R. 1880. Étude sur les fossiles de la vallée de la Cettina en Dalmatie. D. Bardin, Saint-Germain.

BRUSINA S. 1866. Contribuzione pella fauna dei molluschi Dalmati. Verhandlungen der Kaiserlich-königlichen Zoologisch-botanisch Gesellschaft 16: 1-134.

BRUSINA S. 1902. Iconographia Molluscorum Fossilium in tellure tertiaria Hungariae, Croatiae, Slavoniae, Dalmatiae, Bosniae, Herzegovinae, Serbiae and Bulgariae inventorum. Officina Soc. Typographicae, Agram.

EDGAR R. C. 2004. MUSCLE: multiple sequence alignment with high accuracy and high throughput. Nucleic Acids Res. 32: 1792-1797. http://dx.doi.org/10.1093/nar/ gkh340

ESU D. 2008. A new species of Tanousia Servain (Gastropoda, Hydrobiidae) from the Early Pleistocene of EmiliaRomagna (Northern Italy). Boll. Soc. Paleont. Italiana 47: 45-49.
EsU D., Gianolla D. 2007. The occurrence of the genus Tanousia Servain (Mollusca, Gastropoda, Hydrobiidae) in the Middle Pleistocene Piànico-Sèllere Basin (Bergamo, Northern Italy). Quaternary Intern. 190: 4-9. http://dx.doi.org/10.1016/j.quaint.2007.11.006

ESU D., KOTSAKIS T. 1996. A Tanousia from the late Middle Pleistocene of the Italian peninsula (Gastropoda: Prosobranchia: Hydrobiidae). Arch. Moll. 125: 105-108.

FALNIOWSKI A. 1990. Anatomical characters and SEM structure of radula and shell in the species-level taxonomy of freshwater prosobranchs (Mollusca: Gastropoda: Prosobranchia): a comparative usefulness study. Folia Malacol. 4: 53-142.

FALNIOWSKI A. 2011. Tanousia zrmanjae. In: IUCN 2013. IUCN Red List of Threatened Species. Version 2013.2. $<$ www.iucnredlist.org > . Downloaded on 10 January 2014.

FALNIOWSKI A., BERAN L. 2015. Belgrandiella A. J. Wagner, 1928 (Caenogastropoda: Truncatelloidea: Hydrobiidae): how many endemics? Folia Malacol. 23: 187-191. http://dx.doi.org/10.12657/folmal.023.015

FALNIOWSKI A., PEŠIĆ V., GLÖER P. 2014. Montenegrospeum Pešić et Glöer, 2013: a representative of Moitessieriidae? Folia Malacol.22:263-268.http://dx.doi.org/10.12657/ folmal.022.023

FALNIOWSKI A., SZAROWSKA M. 2011. A new genus and new species of valvatiform hydrobiid (Rissooidea; Caenogastropoda) from Greece. Moll. Res. 31: 189-199.

FALNIOWSKI A., SZAROWSKA M. 2013. Phylogenetic relationships of Dalmatinella fluviatilis Radoman, 1973 (Caenogastropoda: Rissooidea). Folia Malacol. 21: 1-7. http://dx.doi.org/10.12657/folmal.021.001

Folmer O., Black M., HoeH W., Lutz R. A., VRIJENHOEK R. C. 1994. DNA primers for amplification of mitochondrial cytochrome $\mathrm{c}$ oxidase subunit I from diverse 
metazoan invertebrates. Mol. Mar. Biol. Biotechnol. 3: 294-299.

GitTenberger E., JANSSEn A. W., KuijPer W. J., KuijPer J. G. J., MeIJer T., VAN DeR VEldE G., DE VRIES J. N., PeEters G. A. 1998. De Nederlandse zoetwatermollusken. Recente en fossiele weekdieren uit zoet en brak water. Nederlandse fauna 2. Nationaal Natuurhistorisch Museum Naturalis, Utrecht.

GLÖER P. 2002. Mollusca I. Süsswassergastropoden Nord und Mitteleuropas. Bestimmungsschlüssel, Lebensweise, Verbreitung. 2. neubearbeitete Auflage. Die Tierwelt Deutschlands 73. ConchBooks, Hackenheim.

HALl T. A. 1999. BioEdit: a user-friendly biological sequence alignment editor and analysis program for Windows 95/98/NY. Nucleic Acids Symp. Ser. 41: 9598.

Herbich F., NeUmaYR M. 1875. Beiträge zur Kenntnis fossiler Binnenfaunen. VII. Die Süsswasserablagerungen im südöstlichen Siebenbürgen. Jahrb. geol. Reichsanstalt 25: 401-431.

Hershler R., PONDER W. F. 1998. A review of morphological characters of hydrobioid snails. Smithsonian Contrib. Zool. 600: 1-55. http://dx.doi.org/10.5479/ si.00810282.600

JEKELIUS E. 1932. Fauna Neogenă a României. Die Molluskenfauna der dazischen Stufe des Beckens von Braşov. Memoriile Institutului Geologic al României 2: 1-118.

JeKelius E. 1944. Sarmat und Pont von Soceni (Banat). Memoriile Institutului Geolologic al României 5: 1-167.

KABAT A. R., HeRSHLER R. 1993. The prosobranch snail family Hydrobiidae (Gastropoda: Rissooidea): review of classification and supraspecific taxa. Smithsonian Contrib. Zool. 547: 1-94. http://dx.doi.org/10.5479/ si.00810282.547

KONDRASHOV P. E. 2007. New gastropod species from the Pleistocene of the Upper Don basin. Paleontol. J. 41: 513519. http://dx.doi.org/10.1134/S0031030107050061

MADSEN V., NORDMANN V. 1901. Det interglaciale Nematurella Ler ved Gudbjerg paa Fyn. Meddelelser fra Dansk Geologiske Forening 8: 23-30.

MeIjER T. 1989. Notes on quaternary freshwater Mollusca of the Netherlands, with descriptions of some new species. Mededelingen Van de Werkgroep voor Tertiaire en Kwartaire Geologie 26: 145-181.

Miller M. A., Pfeiffer W., SchWARTZ T. 2010. Creating the CIPRES Science Gateway for inference of large phylogenetic trees. Proceedings of the Gateway Computing Environments Workshop (GCE), 14 Nov., New Orleans, LA: 1-8. http://dx.doi.org/10.1109/ GCE.2010.5676129

Nei M., Kumar S. 2000. Molecular evolution and phylogenetics. Oxford University Press, Oxford.

PREECE R. C. 1990. The molluscan fauna of the Middle Pleistocene interglacial deposits at Little Oakley, Essex, and its environmental and stratigraphical implications. Phil. Trans. R. Soc. London B 328: 387-407. http://dx. doi.org/10.1098/rstb.1990.0118
PREECE R. C. 2001. Molluscan evidence for differentiation of interglacials within the Cromerian Complex. Quatern. Sci. Rev. 20: 1643-1656. http://dx.doi. org/10.1016/S0277-3791(01)00032-4

RADOMAN P. 1973. New classification of fresh and brackish water Prosobranchia from the Balkans and Asia Minor. Posebna Izdanja, Prirodnjacki Musej u Beogradu 32: $1-30$.

RADOMAN P. 1983. Hydrobioidea a superfamily of Prosobranchia (Gastropoda). I. Systematics. Serbian Academy of Sciences and Arts, Monographs 547, Department of Sciences 57: 1-256.

RADOMAN P. 1985. Hydrobioidea, a superfamily of Prosobranchia (Gastropoda). II. Origin, zoogeography, evolution in the Balkans and Asia Minor. Faculty of Science - Department of Biology Monographs, 1, Institute of Zoology Beograd 1: 1-173.

Roth L. V. 1881. Beitrag zur Kenntniss der Fauna der neogenen Süsswasser-Ablagerungen im Széklerlande. Földtani Közlöny 11: 13-24, 64-76.

SCHLICKUM W. R. 1974. Die Gattung Tanousia Servain. Arch. Moll. 104: 73-79.

SCHLICKUM W. R., SCHÜTT H. 1971. Lithoglyphulus, eine neue Prosobranchiergattung. Arch. Moll. 101: 289-293.

SCHÜTT H. 1976. Zur Molluskenfauna der unterpliozänen Süßwasserkalke von Attika. Arch. Moll. 107: 35-61.

SERVAIN G. 1881. Histoire malacologique du Lac Balaton en Hongrie. S. Le Jay et Cie, Poissy. http://dx.doi. org/10.5962/bhl.title.10458

STAMATAKIS A. 2014. RAxML Version 8: A tool for Phylogenetic Analysis and Post-Analysis of Large Phylogenies. Bioinformatics 30: 1312-1313. http://dx. doi.org/10.1093/bioinformatics/btu033

Strong E. E., Gargominy O., Ponder W. F., Bouchet P. 2008. Global diversity of gastropods (Gastropoda; Mollusca) in freshwater. Hydrobiologia 595: 149-166. http://dx.doi.org/10.1007/s10750-007-9012-6

SZAROWSKA M. 2006. Molecular phylogeny, systematics and morphological character evolution in the Balkan Rissooidea (Caenogastropoda). Folia Malacol. 14: 99168. http://dx.doi.org/10.12657/folmal.014.014

SZAROWSKA M., FALNIOWSKI A. 2011. An unusual, flagellum-bearing hydrobiid snail (Gastropoda: Rissooidea: Hydrobiidae) from Greece, with descriptions of a new genus and a new species. J. Nat. Hist. 45: 2231-2246. http://dx.doi.org/10.1080/00222933.2011.591067

SZAROWSKA M., FALNIOWSKI A. 2014. Horatia Bourguignat, 1887: is this genus really phylogenetically very close to Radomaniola Szarowska, 2006 (Caenogastropoda: Rissooidea)? Folia Malacol. 22: 31-39. http://dx.doi. org/10.12657/folmal.022.003

SZAROWSKA M., GRZMIL P., FALNIOWSKI A., SIRBU I. 2007. Grossuana codreanui (Grossu, 1946) and the phylogenetic relationships of the East Balkan genus Grossuana (Radoman, 1973) (Gastropoda: Rissooidea). Hydrobiologia 579: 379-391. http://dx. doi.org/10.1007/s10750-006-0530-4

TAMURA K., STECHER G., PETERSON D., FiliPSKi A., KuMAR S. 2013. MEGA6: Molecular evolutionary genetics anal- 
ysis version 6.0. Mol. Biol. Evol. 30: 2725-2729. http:// dx.doi.org/10.1093/molbev/mst197

WILKE T. 2003. Salenthydrobia gen. Nov. (Rissooidea: Hydrobiidae): a potential relict of the Messinian salinity crisis. Zool. J. Linn. Soc. 137: 319-336. http://dx.doi. org/10.1046/j.1096-3642.2003.00049.x

WILKE T., DAVIS G. M. 2000. Infraspecific mitochondrial sequence diversity in Hydrobia ulvae and Hydrobia ventrosa (Hydrobiidae: Rissoacea: Gastropoda): Do their different life histories affect biogeographic patterns and gene flow? Biol. J. Linn. Soc. 70: 89-105. http://dx.doi. org/10.1111/j.1095-8312.2000.tb00202.x

WiLkE T., DAVIS G. M., FALNIOWSKI A., GIUSTI F., BODON M., SZAROWSKA M. 2001. Molecular systematics of Hydrobiidae (Gastropoda: Rissooidea): testing monophyly and phylogenetic relationships. Proc. Acad. Nat. Sci. Philadelphia 151: 1-21. http:// dx.doi.org/10.1635/0097-3157(2001)151 [0001:MSOHMG]2.0.CO;2
Wilke T., HaAse M., Hershler R., LiU H. P., Misof B., PONDER W. 2013. Pushing short DNA fragments to the limit: Phylogenetic relationships of 'hydrobioid' gastropods (Caenogastropoda: Rissooidea). Mol. Phyl. Evol. 66: 715-736. http://dx.doi.org/10.1016/j. ympev.2012.10.025

XIA X. 2013. DAMBE: A comprehensive software package for data analysis in molecular biology and evolution. Mol. Biol. Evol. 30: 1720-1728. http://dx.doi. org/10.1093/molbev/mst064

XiA X., Xie Z., SAlemi M., Chen L., WANG Y. 2003. An index of substitution saturation and its application. Mol. Phyl. Evol. 26: 1-7. http://dx.doi.org/10.1016/S10557903(02)00326-3

Received: June 10th, 2015

Revised: August 28th, 2015

Accepted: September 10th, 2015

Published on-line: November 16th, 2015 